\title{
INFLAMMATORY ABDOMINAL AORTIC ANEURYSM AND RETROPERITONEAL FIBROSIS
}

\section{INFLAMATORNA ANEURIZMA ABDOMINALNE AORTE I RETROPERITONEALNA FIBROZA}

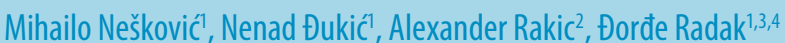

\section{Summary}

The inflammatory aneurysm of abdominal aorta (IAAA) accounts for 3-11\% of all abdominal aortic aneurysms, and occurs predominantly in men. It has similar pathological mechanisms like idiopathic retroperitoneal fibrosis (IRF) and perianeurysmal retroperitoneal fibrosis (PRF), thus presenting the same non-specific systemic inflammatory disorder known as chronic periaortitis (CP).

Recognition of CP early in its course is important in order to reduce morbidity due to complications, such as renal failure and mortality from aortic rupture. However, the initial symptoms of $C P$ are non-specific, which makes early clinical diagnosis extremely difficult.

Various studies have shown favorable outcomes following corticosteroid treatment in nearly $90 \%$ of patients. The positive effects of adding different immunosuppressants to corticoid therapy have established such "duo-therapy" as a durable treatment option. Also, cessation of smoking has a positive effect on disease course and it should be an integral part of every treatment regimen.

Operative repair of the abdominal aortic aneurysm is considered to be the definitive treatment for IAAA. The effects of both open and endovascular interventions on the inflammatory component however remain unclear. Resolution of periaortic fibrotic tissue after surgery for IAAA is still debated. Some investigators have reported a complete resolution while the others have noted partial regression and even persistence of the inflammatory cuff.

Current treatment strategies are based upon "the best available evidence", mostly derived from clinical experience obtained by case series involving a small number of patients. Studies of a higher evidence level are very much needed to adjust our approach to such patients and to establish guidelines for treating this complex and serious disorder.

Keywords: inflammatory abdominal aortic aneurysm, retroperitoneal fibrosis, chronic periaortitis, corticosteroids, immunosuppressants, abdominal aortic surgery, EVAR

\section{Sažetak}

Inflamatorne aneurizme čine 3-11\% svih aneurizmi abdominalne aorte (AAA), javljajući se pretežno u muškaraca. Patofiziološki mehanizam nastanka ovih aneurizmi isti je kao i kod idiopatske i perianeurizmalne retroperitonealne fibroze, čineći tako nespecifični sistemski inflamatorni entitet poznat kao hronični periaortitis. Rano prepoznavanje ovog stanja važno je sa aspekta smanjenja morbiditeta i mortaliteta, pre svega otkazivanja bubrega i rupture aneurizme aorte.

Mnoge studije su pokazale značaj tretmana preparatima kortikosteorida, dovodeći do željenih efekata u skoro 90\% bolesnika. Dodavanjem različitih imunosupresivnih lekova postavljeni su osnovi „dualne terapije“ kao dugoročnog rešenja. Takođe, prekid pušenja pozitivno utiče na tok bolesti i predstavlja integralni deo svakog režima lečenja.

lako se smatra da je operativno lečenje AAA definitivna terapijska opcija, efekti otvorene i endovaskularne hirurgije na inflamatornu komponentu AAA ipak ostaju nerazjašnjeni. Rezolucija periaortnog fibroznog tkiva nakon hirurškog lečenja i dalje ostaje predmet debate. Neki autori su prijavilni potpunu rezoluciju, dok su drugi primetili parcijalnu regresiju uz perzistirajući paraaortalni „cuff".

Trenutne strategije lečenja bazirane su na osnovu „najboljih dostupnih dokaza“, uglavnom dobijenih iz kliničkog iskustva baziranog na individualnim slučajevima i istraživanjima sa malim brojem pacijenata. Studije od većeg kliničkog značaja su neophodne kako bismo prilagodili pristup takvim pacijentima i formirali vodiče za lečenje ovog kompleksnog i ozbiljnog poremećaja.

Ključne reči: inflamatorna aneurizma abdominalne aorte, retroperitonealna fibroza, hronični periaortitis, kortikosteroidi, imunosupresivi, hirurgija abdominalne aorte, EVAR.

\section{INTRODUCTION}

An inflammatory aneurysm of abdominal aorta (IAAA) is defined as an aneurysm with a $>1 \mathrm{~cm}$ thick periaortic inflammatory rind, as seen on computed tomography (CT) scan. The term inflammatory aneurysm was introduced by Walker in 1972, who described a group of abdominal aortic aneurysms (AAAs) intraoperatively characterized by a thickened wall, marked perianeurys- mal and retroperitoneal fibrosis and adhesions to adjacent organs (1).

IAAA, idiopathic retroperitoneal fibrosis (IRF) and perianeurysmal retroperitoneal fibrosis (PRF) are actually various clinical presentations of the same non-specific systemic inflammatory disorder known as chronic periaortitis (CP) and do not represent separate entities. While IAAA is characterized by the triad of back/ab- 
dominal pain, pulsatile abdominal aortic aneurysm and an elevated erythrocyte sedimentation rate (ESR), IRF and PRF cause even less specific symptoms and may lead to obstruction of the ureters and adjacent abdominal structures or even an end-stage renal disease (2-6). These varieties of RF can be idiopathic or secondary to other causes, the latter remaining beyond the scoop of this study.

Despite differences in their clinical presentation, all abovementioned varieties of $\mathrm{CP}$ are sharing identical histopathological characteristics: advanced atherosclerosis of the abdominal aorta, the development of fibroblast proliferation and chronic inflammatory infiltrates in the aortic adventitia, medial thinning in dilated or undilated aorta with a varying degree of periaortic fibrosis and deposits, and extension to involve adjacent structures (7). Apart from an increased aortic diameter in IAAA, there are no other differences in histology between IAAA and IRF. These conditions present a challenge for a surgeon and treatment strategies have not been clearly defined yet (8).

\section{INCIDENCE AND EPIDEMIOLOGY}

The IAAA accounts for $3-11 \%$ of all AAAs. It occurs predominantly in men (male to female ratio from 6:1 to $30: 1$ ). The mean age at presentation is $62-68$ year, which is 5-10 years younger than in patients with non-inflammatory AAAs $(1,9-13)$. The data on its annual incidence are incoherent due to overlap with IRF, varying from 0,1 to 1,3 per 100.000 persons per year $(14,15)$. Most studies indicate that IRF occurs earlier than IAAA, at the age of 40 to 60 years, and is twice more frequent in men (16-18).

The proportion of smokers in IAAA patients is significantly higher (77-100\%). (11) There is evidence that a familial tendency to aneurysm formation is 10 times more frequent in patients with inflammatory aneurysm, leading to the assumption of a genetic predisposition (19).

Interestingly, the exposure to asbestos is a well-known risk factor for developing $\operatorname{IRF}(14,20)$, but its relation to IAAA remains unclear.

\section{Pathogenesis}

$\mathrm{CP}$ and its spectrum of clinical disorders that include IAAA and IRF are characterized by chronic inflammation in the presence of advanced atherosclerosis (6). The etiology of the clearly antigen-triggered inflammatory response has not been fully understood so far and currently there are two leading theories on issue of the pathogenesis of CP.
The first theory is that RF is the expression of a vast local inflammatory response to aortic atherosclerosis and degradation of the aortic wall $(7,21-23)$.

Autoimmunity to a component of atherosclerotic plaque, oxidized low-density lipoprotein (LDL), and ceroid has been proposed as the antigenic stimulus in the initiation of the inflammatory process. Degradation products from lipids deposited in the wall, elastin degradation products, etc. may lead in the further course to the disintegration of the extracellular matrix via the release and activation of proteolytic enzymes from immune cells, e. g. metallomatrix proteases and can finally cause aneurysm genesis through inflammatory degradation of the aortic wall (24).

The second leading theory is that IAAA/RF is the expression of a systemic autoimmune disease (25). Vaglio et al reported vasculitis with fibrinoid necrosis involving the aortic vasa vasorum and the small and medium retroperitoneal vessels, suggesting that $\mathrm{CP}$ could be a systemic autoimmune disease, perhaps involving a vasculitic process of small and medium vessels (22). This supports previous studies, which reported a prevalence of small-and medium-vessel vasculitis in $10-80 \%(26,27)$. The association of various autoimmune diseases, such as systemic lupus erythematosus, rheumatoid arthritis, ankylosing spondylitis, Wegener's granulomatosis, polyarteritis nodosa, and giant cell arteritis, with periaortitis and their response to steroids and other immunosuppressive agents further strengthens the concept of autoimmunity (27-32).

\section{Clinical manifestations}

Recognition of CP early in its course is important in order to reduce morbidity due to complications, such as renal failure and mortality from aortic rupture. However, the initial symptoms of $\mathrm{CP}$ are non-specific, which makes early clinical diagnosis extremely difficult. As a consequence, the diagnosis is often delayed until significant organ involvement, such as ureteral obstruction and/or renal failure, is present.

The onset of IAAA is virtually always associated with abdominal, back or flank pain (65-90\%), which are seen significantly less frequently in non-inflammatory aneurysms, namely $8 \%$ versus $18 \%$ (33). Lack of appetite and weight loss are seen in almost $50 \%$ of patients. Fever is seen in isolated cases but it does not represent typical element of the clinical picture (9).

The onset of IRF is characterized with even less specific clinical presentation. The most frequent clinical manifestation of IRF is a dull pain in the lower back, abdomen or flank. Additional symptoms include malaise, anorexia, vomiting, fever, weight loss, vomiting, lower extremity oedema and testicular pain (16). 
At earlier stages of IAAA and IRF there are no specific abnormalities in laboratory findings, but inflammatory markers, such as erythrocyte sedimentation rate and C-reactive protein that are elevated in the majority of patients (34). Leukocytosis is seen in isolated cases. In patients with more advanced disease and depending upon the presence of ureteral obstruction impaired renal function is present in the majority of patients while urinary sediment tends to be normal (15).

\section{DiAgnosis}

Due to unspecific clinical manifestations, in the first place it is of crucial importance to "think of it". Currently, the diagnosis of IAAA/IRF mostly depends upon imaging studies. Ultrasonography can detect the presence of AAA, urinary tract obstruction or hydronephrosis (35). It can even reveal a poorly emarginated hypoechoic retroperitoneal mass which, combined with coexisting hydronephrosis, might lead to correct diagnosis of IRF.

However, it is definitely not the most optimal imaging study for the diagnosis of IAAA or IRF. CT definitely provides more complete information on IAAA than ultrasound. At CT findings, the aortic wall thickening in IAAA is usually limited to the anterior and lateral aspect of the aorta while the posterior aortic wall remains spared $(37,38)$. (Figure 1)

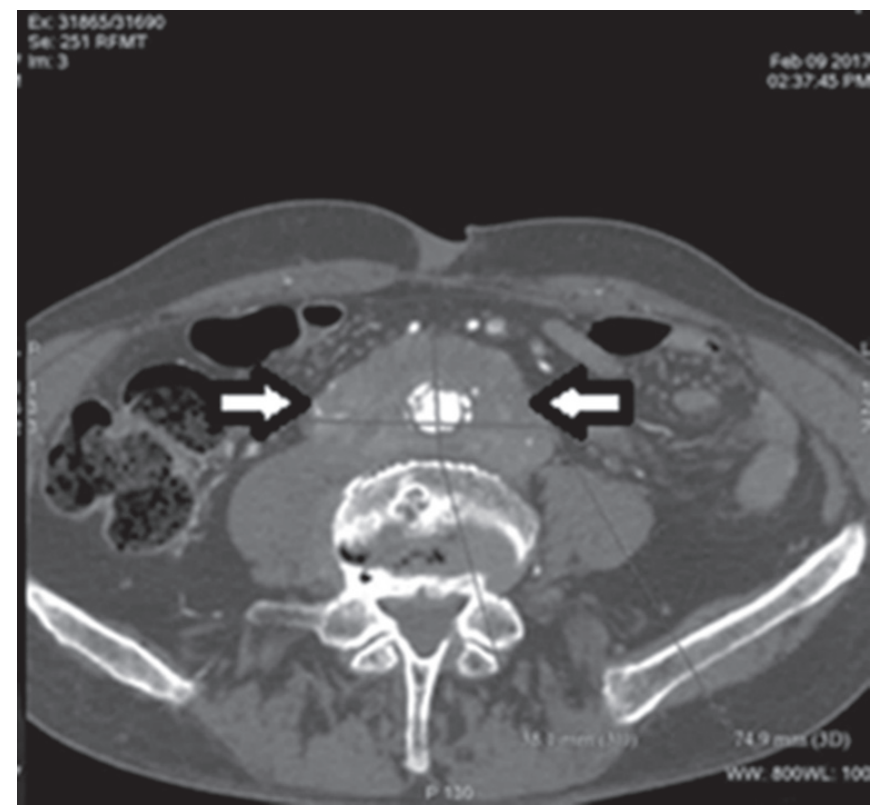

Figure 1. Computed tomography scan findings of periaortal retroperitoneal fibrosis

$\mathrm{CT}$ also plays a key role in diagnosis of IRF because it is characterized by certain pathognomonic findings (39). A confluent soft tissue density indicates a mass that develops and surrounds the aorta and often encircles the inferior vena cava. In $25 \%$ of the cases, a lymphadenopathy neighbouring the mass is seen (15). A contrast-enhanced CT can also visualize the degree of fibrosis and evaluate response to therapy, so it plays a very import- ant role in elimination of other pathology (lymphadenopathy, tumors, etc).

CT-guided biopsy is highly desired in unclear cases of IRF but there is no consensus on its routine application so far. Current literature suggests taking a biopsy in subsequent settings, such as clinical, laboratory, and/or radiological findings that suggest an underlying infection or malignancy, an atypical location of the fibro-inflammatory mass, a limited experience and/or expertise regarding RF, and unresponsiveness to initial therapy.

Magnetic resonance imaging delivers findings similar to those of a CT while offering advantage of avoiding contrast (40). Several studies have proposed that a signal in T2-weighed scans is more efficient in indicating malignancies and that a better definition of the RF might be obtained $(40,41)$.

Positron emission tomography has a low specificity because it cannot distinguish between IRF and secondary forms of RF but it is a reliable technique to assess the metabolic or inflammatory activity of the disease and may lead to early diagnosis of relapses (42).

\section{DIFFERENTIAL DIAGNOSIS}

The thickness of aortic wall and inflammatory rind surrounding the aorta on CT makes differential diagnosis between IAAA and non-inflammatory AAA relatively easy.

The differential diagnosis of IRF is more complex and it includes malignancies (lymphoma, sarcomas, etc.), infections such as tuberculosis, an inflammatory pseudotumor, retroperitoneal fibromatosis, Erdheim-Chester disease and virtually all other malignant and non-malignant retroperitoneal masses $(43,44)$. In patients who have a radiologic diagnosis of $\mathrm{RF}$, causes of secondary RF should be sought: the history of radiation therapy, prior surgery such as lymphadenectomy, colectomy, or aneurysmectomy, the medication history, particularly searching for drugs associated with RF, including ergot-derivatives, methysergide, bromocriptine, beta blockers, methyldopa, hydralazine, and analgesics. Upon elimination of possible causes of secondary RF, diagnosis of primary or IRF can be established.

Whenever other pathology cannot be excluded by CT or magnetic resonance imaging (MRI), a biopsy should be performed to establish the diagnosis (45).

\section{Treatment STRATEgies}

The main goals of treatment of $\mathrm{CP}$ are to stop the progression of the disease, to inhibit relapses, and to prevent 


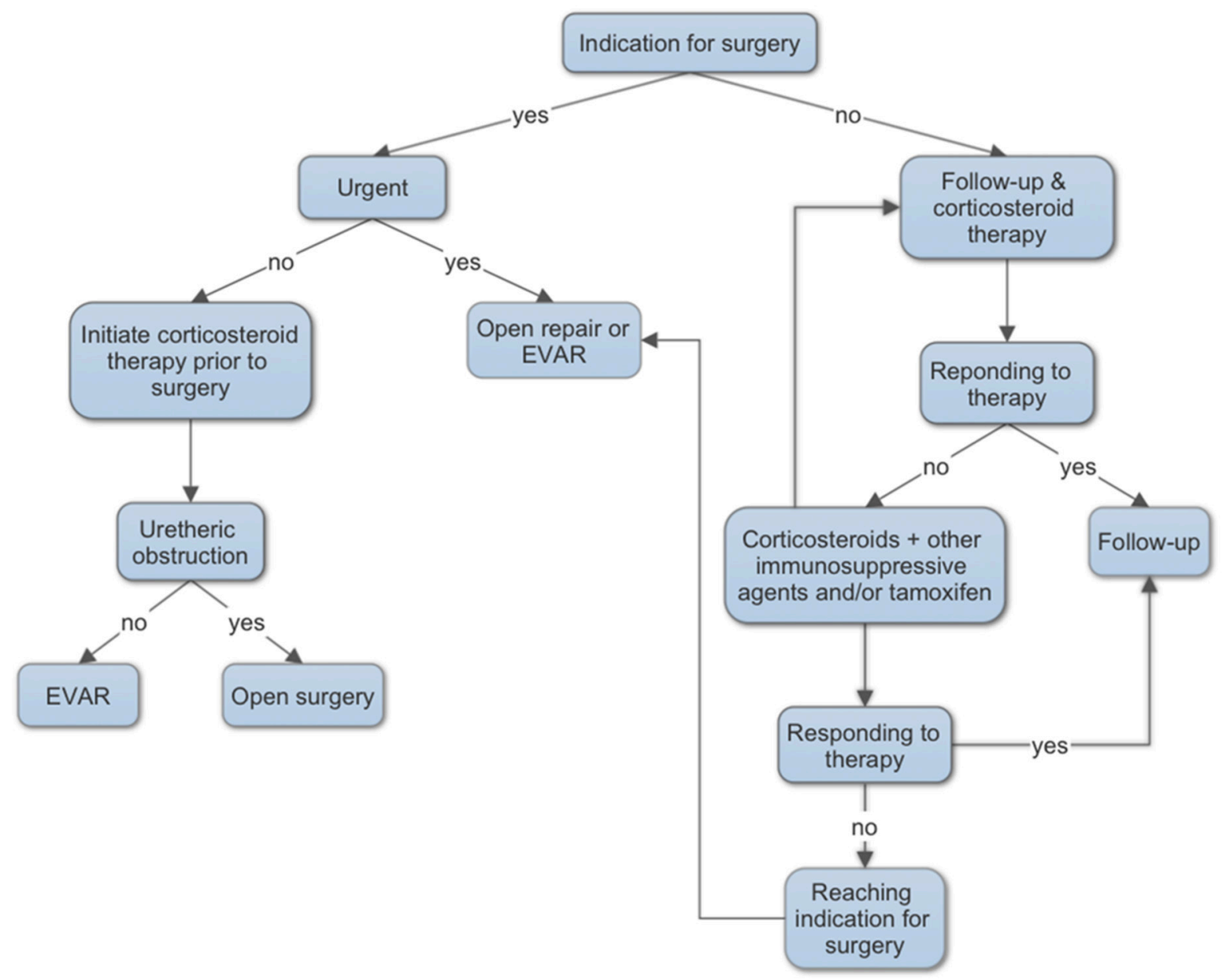

Figure 2. Treatment algorithm for patients with inflammatory abdominal aortic aneurysm and retroperitoneal fibrosis

development of complications such as urinary obstruction or aneurysm rupture. As soon as the diagnosis has been established, medical and/or surgical treatment is to be initiated. (Figure 2) Since there are no randomized trials to guide management of $\mathrm{CP}$, treatment strategies are primarily based upon clinical experience obtained by case series. Most of these studies are retrospective and uncontrolled, and involve small number of patients $(4,5)$.

\section{CORTICOSTEROID TREATMENT}

Various studies have shown positive results following corticosteroid treatment in nearly $90 \%$ of patients, demonstrated by resolution of clinical symptoms, normalization of inflammatory markers, improvement of obstructive complications and significant reduction of the fibro-inflammatory mass (46-51). Patients responding to steroid treatment experience a mortality of less than $10 \%$, which was measured over many years of follow-up and this excludes cases regarding malignancies $(52,53)$. These and other similar observations lead to a general agreement among clinicians that therapy with corticosteroids plays a fundamental role in treatment and represents the first-line in treatment.

In a recent review, Caspary et al also suggested that in patients with infectious condition, once the infection has been ruled out, immunosuppressant agents should be applied to all forms of inflammatory aortic disease and that corticosteroid treatment should be the primary choice (54). Although standards for the dose and duration of steroid treatment are still lacking, there is a general agreement that treatment should be initiated at a medium-high dose, which is then to be tapered under close monitoring.

IRF can be treated with prednisone $1 \mathrm{mg} / \mathrm{kg}$ per day (maximum dosage is $80 \mathrm{mg}$ daily) for approximately four weeks. When improvement is detected, dosage is to be tapered over to about two or three months to $10 \mathrm{mg}$ /day which is to be maintained for the following 6 to 18 months. Karder et al showed that treatment with prednisolone has led to disease remission in 9 of 11 patients with IRF (55). Initial dosage was $60 \mathrm{mg}$ every second day for 8 weeks, which was tapered to $5 \mathrm{mg}$ in the following 5 months.

Afterwards, Bommel et al reported satisfactory results in $75 \%$ of patients with applying prednisone $60 \mathrm{mg}$ daily for 6 weeks, and then tapering it to $10 \mathrm{mg}$ daily over the following two months (51). With regard to other regimens, lower or higher doses also presented positive results in curbing disease activity and preserving renal function $(48,56)$. While tapering the dosage, $25-50 \%$ patients are showing relapse of disease $(48,51)$. These relapsing patients show positive results after increasing corticosteroid therapy dosage (48). 
Vaglio et al presented results in which the fibro-inflammatory mass reduces in mass to a greater extent during the first month of corticosteroid treatment, whereas in later phases it seems to stabilize (6). Serious comorbid conditions contraindicating surgery and persistence of symptoms and inflammation following surgery may be other indications for steroids (57).

The benefit from corticosteroid therapy differs among patients with $\mathrm{CP}$, but predictors of responsiveness to this therapy are still lacking. Older patients and patients in whom the biopsy shows a great inflammatory component seem to experience greater benefit (58). Patients undergoing the treatment should be monitored closely by control of inflammatory markers, serum creatinine and imaging studies. Despite the lack of consensus, it seems reasonable to perform blood tests every 4-8 weeks and imaging studies every $2-4$ months $(59,60)$. In addition, as the cessation of smoking has a positive effect on disease course, it should be an integral part of every treatment regimen (35).

\section{IMMUNOSUPPRESSIVE THERAPY}

An inadequate response to corticosteroids alone calls for the adding of another immunosuppressing agent. The positive effects of adding different immunosuppressants to corticoid therapy have been reported by Marcolongo et al (56). Following four to six months of no response to initial therapy with corticosteroids alone, it is preferred to add methotrexate, due to positive responses in other immunological mediated diseases that follow a chronic way of development (61). Starting dosage is 7,5 mg/week after which the dose is to be increased by $2,5 \mathrm{mg} \mathrm{ev}$ ery month up to the moment when a significant effect is seen or the toxicity limits have been reached (maximum dose is $20 \mathrm{mg}$ /week). If there is a lack of improvement within four to six weeks, a CT scan and biopsy are highly desired in IRF to verify diagnosis.

Azathioprine has been also used effectively as steroid-sparing agents/to lower the dose and in patients unresponsive to steroids alone $(8,27,62)$. Cyclophosphamide may be useful in severe cases especially if vasculitis is present in the fibrotic mass (63). Scheel et al conducted a prospective study comprised of 28 patients receiving "duo-therapy" consisting of $40 \mathrm{mg}$ prednisone tapered over 6 months and mycophenolate mofetil $1 \mathrm{~g}$ twice daily for a mean of 2 years (64). All patients showed remission of disease and normalization of creatinine and ESR levels, and 25/28 patients showed at least $25 \%$ shrinkage of the fibro-inflammatory mass.

As a last resort for corticosteroid-resistant cases, frequently relapsing disease or contraindication to steroids, tamoxifen, a selective estrogen receptor modulator, has been used in the treatment of IRF $(53,65-69)$. Tamoxi- fen has been found to be effective as a single agent and in combination with steroids. Van Bommel et al administered tamoxifen $20 \mathrm{mg}$ twice daily in a group of $19 \mathrm{pa}-$ tients diagnosed with CP, of which 15 had satisfactory results defined by a decrease in CRP and ESR levels (53). Fourteen of these 15 patients showed decrease of the fibro-inflammatory mass on the CT. Vaglio et al performed an open-label randomized controlled trial comparing therapy with prednisone in comparison with tamoxifen therapy (16).

After a follow up of 18 months the relapse rates were $17 \%$ for prednisone and $50 \%$ for tamoxifen with the adverse effects more frequent in the prednisone group. However, the evidence on role of tamoxifen in treatment of IRF so far has been limited to a few positive case reports and small series of patients with observed resolution in fibrosis $(63,69-73)$. Further controlled studies are obviously needed to define more precisely the role of tamoxifen in treatment to CP-related disorders.

The interest in biologicals in treatment of CP related disorders has been growing over the last couple of years. Severel reports have shown positive responses resulting from the use of biologic agents. Couderc et al presented results suggesting that RF may occur alongside rheumatoid arthritis when patients are undergoing a treatment with anti-TNF-alpha, but the link between these agents and the developing disease remains unclear (74). Catanoso et al showed that infliximab led to improvement of refractory CP (75). Infliximab was given in a dosage of $5 \mathrm{mg} / \mathrm{kg}$ at week $0,2,6$, and 8 and after that weekly for the duration of 36 months. Vaglio et al presented the positive results of treatment with tocilizumab for a patient with refractory disease that was given $8 \mathrm{mg} / \mathrm{kg}$ once every four weeks for six months, which led to the improvement of symptoms and normalization of inflammatory markers (76).

\section{SURgICAL TREATMENT}

Combined medical therapy along with surgery remains controversial, although scarce studies reported good results (77). When a severe ureteral obstruction is already present, immediate relief is demanded through either ureteral stenting or percutaneous nephrostomy simultaneously with application of corticosteroid therapy. Fry et al have shown that such initial conservative treatment is preferred over direct surgery (48). Wagenknecht et al, in their large retrospective series, reported a reduction of ureteral restenosis from $48 \%$ to $10 \%$ when steroids were used along with surgery in IRF (62).

The potential role of medical therapy in treatment of IAAA has been poorly analyzed (77). Even though a reduction in aneurysm diameter under steroid therapy has not been observed yet, treatment with corticosteroids 
might be justified, while the aneurysm does not reach the operative criteria $(4,6,33,54)$. There are individual reports on the complete resolution of clinical symptoms and all inflammatory changes to the aortic wall and retroperitoneum under steroid therapy (33). Kardar et al. experienced regression of inflammation and fibrosis, therewith facilitating better surgical dissection (55).

As far as IAAA is concerned, the indications for surgical treatment are assessed in much the same way as in non-inflammatory aneurysms. Surgery is recommended when the aneurysm is greater than $5 \mathrm{~cm}$ in maximal transverse diameter, having in mind that the risk of rupture in an aneurysm measuring $5 \mathrm{~cm}$ is around $25 \%$ and postrupture mortality is more than $75 \%$ (78). The frequent onset of pain tends to prompt earlier surgery. Operative repair of the aneurysm is the definitive treatment for IAAA. Traditionally, open surgical repair (OSR) of IAAA was considered much more difficult than in non-inflammatory variety due to inflammatory adhesions involving adjacent organs, such as the duodenum, sigmoid colon, vena cava or ureters. Attempts to detach these structures from the aneurysm can cause damage to these organs and they initially contributed to significantly higher morbidity and mortality compared with non-inflammatory aneurysms $(1,11)$. Improvements in surgical techniques have led to a gradual reduction in the mortality rate, which was virtually comparable with non-IAAA in the 1990 s, namely $6.8 \%$ versus $11 \%(35,37,79)$.

If anatomy permits, there seem to be no other obstacles to endovascular treatment of IAAA. A number of studies have shown that open and endovascular repair have similar results regarding terms of mortality and morbidity $(35,80)$. Puchner et al also concluded that endovascular repair of an IAAA excludes the aneurysms and leads to a decrease in size of the aneurysmal sac and the extent of periaortic fibrosis with acceptable interventional and long-term morbidity (81). In a systematic review, Paravastu et al collected data from 35 studies comprising 999 patients and 21 studies comprising 121 patients who underwent open and endovascular surgical repair (82). The authors concluded that endovascular repair is associated with a lower 1-year mortality when compared to open surgical repair. On the other hand, open surgical repair is preferred in patients diagnosed with hydronephrosis. Recently, Kakkos et al performed a retrospective study of 27 patients with an intact IAAA comparing outcome of the IAAA after OSR and endovascular aneurysm repair (EVAR) and concluded EVAR to be associated with decreased operating time, transfusion needs, hospitalization, and morbidity (83).

The effects of both open and endovascular interventions on the inflammatory component remain unclear. Resolution of periaortic fibrotic tissue after surgery for IAAA is still debated. Some investigators have reported a complete resolution while the others have noted partial regression and even persistence of the inflammatory cuff (84-86). Although Swartbol et al reported that the cytokine response seems to be lower during EVAR comparing to open surgical repair, a regression in fibrotic periaortitis is seen significantly less frequently following $\operatorname{EVAR}(37,87)$.

Van Bommel et al concluded EVAR to be inferior in comparison with open repair in achieving regression of chronic periaortitis (79). It is possible that the endografts themselves are capable of triggering an inflammatory reaction in the aortic wall and directly adjacent structures thereby resulting in a new low-grade periaortic fibrosis as reported in a small number of patients (86). Thus, the indications EVAR, at least in IAAA with ureteral involvement, should be considered from a critical perspective.

\section{Conclussion}

Concomitant presence of inflammatory abdominal aortic aneurysm and retroperitoneal fibrosis generates several diagnostic and therapeutic dilemmas. Reaching an adequate diagnosis is often challenging, while the current treatment strategies for management of various presentations of chronic periaortitis are based upon "the best available evidence", mostly derived from clinical experience obtained by case series involving a small number of patients. Studies of a higher evidence level are very much needed to adjust our approach to such patients and to establish guidelines for treating this complex and serious disorder.

\section{References}

1. Walker D, Bloor K, Williams G, Gillie I. Inflammatory aneurysms of the abdominal aorta. British Journal of Surgery 1972; 59(8):609-614.

2. Crawford J, Stowe C, Safi H, Hallman C, Crawford E. Inflammatory aneurysms of the aorta. Journal of Vascular Surgery 1985; 2(1):113-124.

3. Pennell R, Hollier L, Lie J, Bernatz P, Joyce J, Pairolero P et al. Inflammatory abdominal aortic aneurysms: A thirty-year review. Journal of Vascular Surgery 1985; 2(6):859-869.

4. Van Bommel. Retroperitoneal fibrosis. Neth J Med 2002; 60(6):231-242.

5. Scheel P, Feeley N. Retroperitoneal Fibrosis. Medicine 2009; 88(4):202-207.

6. Vaglio A, Salvarani C, Buzio C. Retroperitoneal fibrosis. The Lancet, 2006; 367(9506):241-251.

7. Parums DV. The spectrum of chronic periaortitis. Histopathology. $1990 ; 16 ; 423-31$

8. Harreby M, Bilde T, Helin P, et al. Retropentoneal fibrosis treated with methylprednisolon pulse and disease-modifying antirheumatic drugs. Scand J Urol Nephrol 1994; 28:237.

9. Sterpetti AV, Hunter WJ, Feldhaus RJ, et al. Inflammatory aneurysm of abdominal aorta: incidence, pathologic and etiologic considerations. $J$ Vasc Surg 1989; 9:643-50.

10. Rose AG, Dent DM. Inflammatory variant of abdominal aortic atherosclerotic aneurysm. Arch Pathol Lab Med 1981; 105:409-13.

11. Rasmussen TE, Hallet JW Jr. Inflammatory aortic aneurysm-a clinical review with new perspectives in pathogenesis. Ann Surg 1997; 225:155-64. 
12. Nitecki SS, Hallett JW Jr, Stanson AW, et al. Inflammatory abdominal aortic aneurysm: new clinical implication from a case-control study. J Vasc Surg 1996; 23:860-9.

13. Hill J, Charlesworth D. Inflammatory abdominal aortic aneurysm-a report of thirty-seven cases. Ann Vasc Surg 1988; 2; 352-7.

14. Uibu T, Oksa P, Auvinen A, et al. Asbestos exposure as a risk factor for retroperitoneal fibrosis. Lancet 2004;363:1422

15. Van Bommel EF, Jansen I, Hendriksz TR, Aarnoudse AL. Idiopathic retroperitoneal fibrosis: prospective evaluation of incidence and clinicoradiologic presentation. Medicine (Baltimore) 2009; 88:193.

16. Vaglio A, Palmisano A, Albenci F, et al. Prednisone versus tamoxifen in patients with idiopathic retroperitoneal fibrosis: an open-label randomised controlled trial. Lancet 2011; 378:338.

17. Koep L, Zuidema GD. The clinical significance of retro- peritoneal fibrosis. Surgery 1977;81:250-7.

18. Kasales, C. \& Hartman, D. Genitourinary case of the day. Retroperitoneal fibrosis. American Journal of Roentgenology 1994; 162(6):1454-1456

19. Mukhtyar C, Guillevin L, Cid M, Dasgupta B, de Groot K, Gross W, et al. EULAR recommendations for the management of large vessel vasculitis. Annals of the Rheumatic Diseases 2009; 68(3):318-323.

20. Goldoni M, Bonini S, Urban ML, et al. Asbestos and smoking as risk factors for idiopathic retropentoneal fibrosis: a case-control study. Ann Intern Med 2014; 161:181.

21. Parums DV, Brown DL, Mitchinson MJ. Serum antibodies to oxidized low-density lipoprotein and ceroid in chronic penaortitis. Arch Pathol Lab Med 1990; 114:383.

22. Vaglio A, Corradi D, Manenti L, Ferretti S, Garini G, Buzio C. Evidence of autoimmunity in chronic periaortitis: a prospective study. Am J Med 2003; 114: 454-62.

23. Ramshaw AL, Roskell DE, Parums DV. Cytokine gene expression in aortic adventitial inflammation associated with advanced atherosclerosis (chronic periaortitis). J Clin Pathol 1994; 47:721

24. Töpel I, Zorger N, Steinbauer M. Inflammatory diseases of the aorta. Gefässchirurgie 2016; 21(S2):80-86.

25. Salvarani C, Calamia K, Matteson E, Hunder G, Pipitone N, Miller D, Warrington K. Vasculitis of the Gastrointestinal Tract in Chronic Periaortitis. Medicine, 2011; 90(1), 28-39.

26. Gilkeson GS, Allen NB. Retroperitoneal fibrosis. A true connective tissue disease. Rheum Dis Clin North Am 1996; 22:23-38.

27. Littlejohn JO, Keystone EC. The association of retroperitoneal fibrosis with systemic vasculitis and HLA-B27: a case report and review of literature. J Rheumatol 1981; 8:665-9.

28. De La Iglesia Martinez F, Grana Gil J, Gomez Veiga F, et al. The association of retroperitoneal fibrosis and ankylosing spondylitis. J Rheumatol 1992; 19:1147-9.

29. Ter Maaten JC, Franssen CFM, Daenekkindt AA, Hoorntje SJ. Triple Wegener's granulomatosis in the urogenital tract. Nephron 1993; 63:358-9.

30. De Roux-Serratrice C, Serratrice J, Granel B, et al. Periaortitis heralding Wegener's granulomatosis. J Rheumatol 2002; 29:392-4.

31. Hautekeete ML, Babany G, Marcellin P, et al. Retroperitoneal fibrosis after surgery for aortic aneurysm in a patient with periarteritis nodosa: successful treatment with corticosteroids. J Intern Med 1990; 228:533-6.

32. Machado EBV, Michet CJ, Ballard DJ, et al. Trends in incidence and clinical presentation of temporal arteritis in Olmsted County, Minnesota, 1950-1985. Arthritis Rheum 1988; 31:745-9.

33. Vaglio, A. \& Buzio, C. Chronic periaortitis: a spectrum of diseases. Current Opinion in Rheumatology 2005; 17(1):34-40.

34. Magrey MN, Husni ME, Kushner I, Calabrese LH. Do acute-phase reactants predict response to glucocoiiicoid therapy in retroperitoneal fibrosis? Arthritis Rheum 2009; 61:674.

35. Tang T, Boyle J, Dixon A, Varty K. Inflammatory abdominal aortic aneurysms. Eur J Vasc Endovasc Surg 2005; 29:353-362.

36. Hoffman GS, et al. Treatment of glucocorti-coid-resistantorrelapsing Takayasu arteritiswith methotrexate. Arthritis and Rheum 1994; 37:578-582.

37. Sultan S, Duffy S, Madhavan P, et al. Fifteen-year experience of transperitoneal management of inflammatory abdominal aortic aneurysms. Eur J Vasc Endovasc Surg 1999; 18:510-514
38. Lindblad B, Almgren B, Bergqvist D, et al. Abdominal aortic aneurysm with perianeurysmal fibrosis: experience from 11 Swedish vascular centers. J Vasc Surg 1991; 13:231-239. 9.

39. Iino, M., Kuribayashi, S., Imakita, S., Takamiya, M., Matsuo, H., \& Ookita, Y. et al. Sensitivity and Specificity of CT in the Diagnosis of Inflammatory Abdominal Aortic Aneurysms. Journal of Computer Assisted Tomography 2002; 26(6):1006-1012.

40. Arrivé L, Hricak H, Tavares NJ, Miller TR. Malignant versus nonmalignant retroperitoneal fibrosis: differentiation with MR imaging. $\mathrm{Ra}$ diology 1989; 172:139.

41. Bakir B, Yilmaz F, Turkay R, et al. Role of diffusion-weighted MR imaging in the differentiation of benign retroperitoneal fibrosis from malignant neoplasm: preliminary study. Radiology 2014; 272:438.

42. Moroni G, Castellani M, Balzani A, et al. The value of (18) F-FDG PET/ $\mathrm{CT}$ in the assessment of active idiopathic retroperitoneal fibrosis. Eur J Nucl Med Mol Imaging 2012; 39:1635.

43. Emiey TE, Cain MP, Faught PR, Davis MM. Ureteropelvic junction obstruction due to inflammatory pseudotumor masquerading as hydronephrosis because of a neuropathie bladder in a child with myelomeningocele. Urology 2001; 58:105.

44. Stoeckle E, Coindre JM, Bonvalot S, et al. Prognostic factors in retroperitoneal sarcoma: a multivariate analysis of a series of 165 patients of the French Cancer Center Federation Sarcoma Group. Cancer 2001; 92:359.

45. Surcel C, Mirvald C, Pavelescu C, Gingu C, Carmen S, Emre H, Ioanel $\mathrm{S}$. Management of idiopathic retroperitoneal fibrosis from the urologist's perspective. Therapeutic Advances in Urology 2015; 7(2):85-99.

46. Van Bommel EF, van Spengler J, van der Hoven B, Kramer P. Retroperitoneal fibrosis: report of 12 cases and a review of the literature. Neth J Med 1991; 39:338-345.

47. Palmisano A, Vaglio A. Chronic periaortitis: a fibro-inflammatory disorder. Best Pract Res Clin Rheumatol 2009; 23:339-353.

48. Fry A, Singh S, Gunda S, Boustead G, Hanbury D, McNicholas T, Farrington K. Successful Use of Steroids and Ureteric Stents in 24 Patients with Idiopathic Retroperitoneal Fibrosis: A Retrospective Study. Nephron Clinical Practice, 2008; 108(3), c213-c220.

49. Warnatz K. Immunosuppressive treatment of chronic periaortitis: a retrospective study of 20 patients with chronic periaortitis and a review of the literature. Ann Rheum Dis 2005; 64:828-833.

50. Van Bommel EF. Retroperitoneal fibrosis. Neth J Med. 2002; 60:231242.

51. Van Bommel EFH, Siemes C, Hak LE, et al. Long-Term Renal and Patient Outcome in Idiopathic Retroperitoneal Fibrosis Treated With Prednisone. Am J Kidney Dis 2007; 49:615-625.

52. Baker LR, Mallison WJ, Gregory MC, Menzies EA, Cattell WR, Whitfield HN, Hendry WF, Wickham JE, Joekes AM. Idiopathic retroperitoneal fibrosis: A retrospective analysis of sixty cases. Br J Urol 1987; 60:497-503.

53. Van Bommel EF, Hendriksz TR, Huiskes AW, Zeegers AG. Brief communication: tamoxifen therapy for nonmalignant retropentoneal fibrosis. Ann Intern Med 2006; 144:101.

54. Caspary, L. Inflammatory diseases of the aorta. Vasa 2016; 45(1):17-29.

55. Kardar AH, Kattan S, Lindstedt E, et al. Steroid therapy for idiopathic retroperitoneal fibrosis: dose and duration. J Urol 2002; 168:550-5.

56. Marcolongo R, Tavolini IM, Laveder F, et al. Immunosuppressive therapy for idiopathic retroperitoneal fibrosis: a retrospective analysis of 26 cases. Am J Med 2004; 116:194

57. Testart J, Plissonnier D, Peillon C, Watelet J. Inflammatory abdominal aortic aneurysm: role of corticosteroid therapy. J Mal Vasc 2002; 25:201-7.

58. Ross JC. Goldsmith HJ. The combined surgical and medical treatment of retroperitoneal fibrosis. British Journal of Surgery 1971;58, 422.

59. Pipitone, N, Salvarani C, Peter H. Chronische Periaortitis. Der Internist, 2009;51(1):45-52.

60. Vaglio A, Palmisano A, Corradi D, et al. Retroperitoneal fibrosis: evolving concepts. Rheum Dis Clin North Am 2007; 33:803-17.

61. Scavalli AS, Spadaro A, Riccieri V, et al. Long-term follow up of lowdose methotrexate therapy in one case of idiopathic retroperitoneal fibrosis. Clin Rheumatol 1995; 14:481-4. 
62. Wagenknecht LV, Hardy JC. Value of various treatments for retroperitoneal fibrosis. Eur Urol 1981; 7:193-200.

63. Binder M, Uhl M, Wiech T, et al. Cyclophosphamide is a highly effective and safe induction therapy in chronic periaortitis: a long-term follow-up of 35 patients with chronic periaortitis. Ann Rheum Dis 2012;71: 311-312

64. Scheel P, Feeley N, Sozio S. Combined Prednisone and Mycophenolate Mofetil Treatment for Retroperitoneal Fibrosis. Annals of Internal Medicine 2011; 154(1), 31.

65. Ozener C, Kiriş S, Lawrence R, et al. Potential beneficial effect of tamoxifen in retroperitoneal fibrosis. Nephrol Dial Transplant 1997; $12: 2166$.

66. Tziomalos K, Knkis N, Karagiannis A, et al. Treatment of idiopathic retroperitoneal fibrosis with combined administration of corticosteroids and tamoxifen. Clin Nephrol 2004; 62:74.

67. Moroni G, Gallelli B, Banfi G, et al. Long-term outcome of idiopathic retroperitoneal fibrosis treated with surgical and/or medical approaches. Nephrol Dial Transplant 2006; 21:2485.

68. Costanzi S, Zoli A, Ferraro PM, et al. A paraneoplastic retropentoneal fibrosis resistent to corticosteroids treated with tamoxifen. Clin Nephrol 2008;70:172

69. Clark CP, Vanderpool D, Preskitt JT. The response of retroperitoneal fibrosis to tamoxifen. Surgery 1991; 109:502.

70. Loffeld RJLF, van Weel TF. Tamoxifen for retroperitoneal fibrosis. Lancet $1993 ; 341: 382$

71. Tonietto G, Agresta F, Della Libera D, Bittesini L. Treatment of idiopathic retroperitoneal fibrosis by tamoxifen. Eur J Surg 1997; 163:231-5.

72. Al-Musawi D, Mitchenere P, Al-Akraa M. Idiopathic retroperitoneal fibrosis treated with tamoxifen only. Br J Urol 1998; 82:442-3.

73. Wilson JL, Proven A, Yacyshyn EA, Griffing L, Luthra HS. Clinical features and response to tamoxifen therapy in patients with retroperitoneal fibrosis. Arthritis Rheum 2000; 43(Suppl.):1385.

74. Couderc M, Mathieu S, Dubost J, Soubrier M. Retroperitoneal Fibrosis During Etanercept Therapy for Rheumatoid Arthritis. The Journal of Rheumatology 2013; 40(11):1931-1933.

75. Catanoso MG, Spaggiari L, Magnani L, et al. Efficacy of infliximab in a patient with refractory idiopathic retroperitoneal fibrosis. Clin Exp Rheumatol 2012; 30:776-778.

76. Vaglio A, Catanoso M, Spaggiari L, Magnani L, Pipitone N, Macchioni $\mathrm{P}$, et al. Brief Report: Interleukin- 6 as an Inflammatory Mediator and
Target of Therapy in Chronic Periaortitis. Arthritis \& Rheumatism 2013; 65(9); 2469-2475.

77. Heidenreich A, Derakhshani P, Neubauer S, et al. Treatment outcomes in primary and secondary retroperitoneal fibrosis. Urologe A 2000; 39:141-8.

78. Jois RN, Gaffney K, IVIarshall T, Scott DG. Chronic periaortitis. Rheumatology (Oxford) 2004;43:1441

79. Bommel EF van et al. Persistent chronic peri-aortitis ('inflammatory aneurysm') after abdominal aortic aneurysm repair: systematic review of the literature. Vasc Med 2008; 13:293-303.

80. Lange C, Hobo R, Leurs LJ, Daenens K, Buth J, Myhre HO. Results of Endovascular repair of inflammatory abdominal Aortic Aneurysms. A report from the EUROSTAR database. European Journal of Vascular and Endovascular Surgery 2005; 29(4):363-370.

81. Puchner S, Bucek RA, Loewe C, et al. Endovascular repair of inflammatory aortic aneurysms: long-term results. AJR Am J Roentgenol 2006; 186:1144-1147.

82. Paravastu SCV, Ghosh J, Murray D, Farquharson FG, Serracino-Inglott F, Walker MG. A systematic review of open versus Endovascular repair of inflammatory abdominal Aortic Aneurysms. European Journal of Vascular and Endovascular Surgery 2009; 38(3):291-297.

83. Kakkos SK, Papazoglou KO, Tsolakis IA, Lampropoulos G, Papadoulas SI, Antoniadis P N. Open versus Endovascular repair of inflammatory abdominal Aortic Aneurysms: A comparative study and Meta-Analysis of the literature. Vascular and Endovascular Surgery, 2015; 49(56):110-118

84. Barrett JA, Wells IP, Roobottom CA, Ashley S. Progression of periaortic fibrosis despite endovascular repair of an inflammatory aneurysm. Eur J Vasc Endovasc Surg 2001; 21:567-8.

85. Hinchliffe RJ, Macierewicz JA, Hopkinson BR. Endovascular repair of inflammatory abdominal aortic aneurysm. J Endovasc Ther 2002; 9:277-81.

86. Vallabhaneni SR, McWilliams RG, Anbarasu A, et al. Perianeurysmal fibrosis: a relative contraindication to endovascular repair. Eur J Vasc Endovasc Surg 2001; 22:535-41.

87. Swartbol P, Truedsson L, Norgren, L. The inflammatory response and its consequence for the clinical outcome following Aortic Aneurysm repair. European Journal of Vascular and Endovascular Surgery, 2001; 21(5):393-400. 